\title{
BRITISH MEDICAL
}

JOURNAL

LONDON SATURDAY 23 JULY 1966

\section{Pointers}

Hastings and the G.M.C. : Lord Cohen of Birkenhead traces Hastings's role in establishing the General Medical Council (p. 191).

Anaemia and Tuberculosis : Dr. P. D. Roberts and his colleagues investigate iron and folate metabolism during treatment of tuberculosis ( $p$. 198).

Folic-acid Deficiency in the Elderly : Dr. A. D. F. Hurdle and Dr. T. C. Picton Williams present evidence of the role of diet (p. 202).

Ornithosis : Dr. P. K. M. Barrett and Dr. M. J. Greenberg describe an outbreak (p. 206).

Obesity and Lipid Levels : Dr. B. M. Rifkind and Dr. T. Begg investigate this relationship in a series of 500 patients (p. 208). See also leader at p. 190.

Haemophilia : Dr. B. M. Fessey and Dr. M. J. Meynell discuss 5 cases of haemorrhage involving the central nervous system (p. 211). Miss M. I. Britten and her colleagues discuss the educational problems facing haemophilic children (p. 224)

Calcium Metabolism in Thyroid Disease : Case report (p. 213).

Barbiturates : Muscle necrosis, calcification, and acute renal failure due to overdose (p. 214).

Pseudocholinesterase : Three generations of an English family homozygous for the fluorideresistant pseudocholinesterase gene (p. 215).

Venous Thrombosis : Dr. R. L. Richards discusses aetiological factors and treatment in his Current Practice article (p. 217).

Surgical Training: Professor R. Y. Calne advocates early selection and better-supervised training (p. 228).

Clinical Sessions at Exeter : Demonstrations of new techniques and symposium on corticosteroid drugs (p. 229).

Conferences: Neurology (p. 231) and Autoimmunity and Genetics (p. 232).

Poisoning with Borax : Warning (p. 233). Leader at p. 188.

Radiation Accident : Report p. 233.

Pertinax : "Without Prejudice” (p. 234).

Lumps in the Breast : Letters p. 235.

Diphtheria : Deaths in Derbyshire (p. 244).

Mental Subnormality : Lords debate (p. 245).

Annual Representative Meeting : Compensation and superannuation (Supplement, pp. 73 and 79). Financing of N.H.S. (p. 74). Public relations (p. 80).

\section{Immunotherapy of Cancer}

Among the various methods that have been tried for destroying cancer cells are those that depend on immunological reactions. One reason why this has been thought a hopeful line of approach is that some animal tumours induced by chemical carcinogens or by viruses contain antigens which are specific for the tumour and may induce host resistance.

Therefore, if spontaneous cancers in man are immunogenic for their host (and it is of importance that some spontaneous cancers in animals are not), there ought to be recorded cases of regression and remission resulting from an immunological reaction. But T. C. Everson ${ }^{1}$ has accepted only 130 cases of spontaneous regression out of more than 1,000 recorded in the literature. Thirteen of them $(10 \%)$ were chorionepitheliomas. This type of tumour should be the most susceptible of all to immunological attack because it is analogous to a graft from foetus to mother, with the graft carrying paternal antigens.

One method of treatment adopted with partial success for such cases is immunization with paternal leucocytes, ${ }^{2-6}$ often combined with other forms of treatment. The serum of the patient may contain antibodies to the paternal leucocytes and platelets. ${ }^{78}$ Despite them, grafts of paternal skin may be tolerated for longer than normal. ${ }^{6}$ This has been interpreted as the tumour mass "capturing " the antibodies as fast as the host could produce them. When the primary tumour has been removed metastases can disappear dramatically, ${ }^{9-11}$ perhaps as a result of the antibody then made available, but possibly because of changes in hormone balance. Whereas the surgical removal of as large a mass of tumour as possible can only be helpful, treatment by irradiation or by antimitotic drugs which suppress immunity will hinder the immune response.

P. Koldovsky ${ }^{12}$ has drawn attention to some of the potential difficulties of the immunotherapy of cancer. These are, first, the inadequacy of the host response to weak, albeit specific, antigens ; secondly, the paralysis of immunological response by overdose of administered antigen; thirdly, changes in immunosensitivity or immunogenicity, or both, of a tumour and its metastases; and, fourthly, the danger of actually speeding-up the growth of the tumour (enhancement), when serum antibodies produced by the host appear to coat the tumour cells in such a way as to reduce their immunosensitivity.

Though it is possible to increase the host's resporse, ${ }^{13}$ it is probably more important to reduce the damage caused by irradiation or drugs. The second difficulty-namely, paralysis of immunological responserequires much more experimental investigation to determine what constitutes an optimum antigenic stimulus and how such antigens should be administered. It is undoubtedly dangerous to homograft living tumour cells in the hope that the recipient will produce cytotoxic antibodies which can be transferred passively to the donor of the tumour. ${ }^{14}$ Reciprocal immunization between patients with renal tumours of a similar origin has also proved therapeutically inadequate. ${ }^{1.5}$. Globulins were detected on the tumour cells post mortem, but also on the normal kidneys cells. 
Immune sera produced in horses or other animals are also limited in use, for as well as bearing a risk of enhancing the tumour they may damage normal organs such as the kidneys. ${ }^{16}$ Nevertheless, such methods have been widely used and encouraging results in terms of remissions have been reported. ${ }^{17} 18$

More recently so-called adoptive immunity with sensitized cells of human or animal origin has been advocated. The patient is given a lethal dose of radiation, and then the destroyed immunological apparatus is re-established by the injection of new cells, which may be sensitized against the tumour's antigens. ${ }^{6}$ It may be possible to overcome the reaction of the grafted cells against the host (secondary disease) either with drugs ${ }^{6}$ or by the prior establishment in adult human donors of immunological tolerance to the recipient. It is generally agreed that it is not possible to make even newborn animals tolerant to all the transplantation antigens of so different a species as man. ${ }^{12}$

E. J. Delorme and P. Alexander ${ }^{19}$ have used sensitized sheep lymph-node cells to depress the growth rate of primary sarcomas induced by a carcinogen in the rat. They encountered anaphylaxis in some of the animals after three or four injections of sheep cells. It seems likely that antibodies will be produced to such cells and that their destruction will put an end to the treatment.

Although the evidence for specific antigens against spontaneous cancers in animals is unsatisfactory, some tumours in man might yet be found suitable for immunotherapy. More attention should be paid to one tumour-chorionepitheliomafor it should be susceptible to immune destruction. It is on the one hand fortunate that this tumour responds so well to chemotherapy and on the other hand unfortunate that no animal analogue of chorionepithelioma appears to exist. If immunotherapy is ineffectual against chorionepithelioma, then the case for using it against other cancers in man is weak.

'Everson, T. C., Ann. N.Y. Acad. Sci., 1964, 114, 721

'Doniach, I., Crookston, J. H., and Cope, T. I., F. Obstet. Gynaec. Brit. Emp., 1958, 65, 553.

Cinader, B., Hayley, M. A., Rider, W. D., and Warwick, O. H., Canad med. Ass. F., 1961, 84, 306

' Hackett, E., and Beech, M., Brit. med. F., 1961, 2, 1123.

Jakoubková, J., Koldovsky, P., Bek, V., Májsky, A., Schneid, V., and Vopatová, M., Neoplasma (Bratisl.), 1965, 12, 531

${ }^{n}$ Mathé, G., Europ. F. Cancer, 1965, 1, 1.

- Dausset, J., Hervet, E., Amiel, J-L., Colombani, J., and Brule, G., 7. nat. Cancer Inst., 1964, 33, 193.

'Robinson, E., Shulman, J., Ben-Hur, N., Zuckerman, H., and Neuman, Z., Lancet, 1963, 1, 300.

${ }^{y}$ Jacobson, F. J., and Enzer, N., Amer. F. Obstet. Gynec., 1959, 78, 868.

10 Garber, E. C., and Morrison, R. H., ibid., 1958, 76, 812 .

1 Garber, E. C., and Morrison, R. H., ibid., 1958, 76,

"Park, W. W., and Lees, J. C., Arch.

${ }^{13}$ Old, L. J., Benacerraf, B., Clarke, D. A., Carswell, E. A., and Stockert, E., Cancer. Res., 1961, 21, 1281.

${ }^{4}$ Scanlon, E. F., Hawkins, R. A., Fox, W. W., and Smith, W. S., Cancer (Philad.), 1965, 18, 782.

${ }^{15}$ Nairn, R. C., Philip, J., Ghose, T., Porteous, I. B., and Fothergill, J. E., Brit. med. F., 1963, 1, 1702.

'De la Pava, S., Nigogosyan, G., and Pickeren, J. W., Arch. intern. Med., $1962,109,391$.

${ }_{17}$ Murray, G., Amer F. Surg., 1965, 109, 763.

18 Carvalho, S. de, Cancer (Philad.), 1963, 16, 306

19 Delorme, E. J., and Alexander, P., Lancet, 1964, 2, 117.

\section{Treatment of Polycythaemia Vera}

The introduction of radioactive phosphorus for the treatment of polycythaemia by J. H. Lawrence in 1938 was a considerable therapeutic advance. Previously it had been the custom to reduce the excess of red cells by giving haemolytic drugs, such as phenylhydrazine, which were notably uncertain in action and difficult to control. Radioactive phosphorus, or phosphorus-32, could be given intravenously or orally in a single dose, and the effects of the one dose lasted for months -or even years in mild cases. Untreated, patients with polycythaemia succumb within a few years to the complications of the disease, particularly cerebral thrombosis or haemorrhage and gastro-intestinal haemorrhage. Phosphorus-32 has extended the average survival to about 13 years. ${ }^{1}$

Experience has shown that not all patients respond satisfactorily to this treatment. For example, L. Szur, S. M. Lewis, and A. W. Goolden ${ }^{2}$ in their series studied in London found that $13 \%$ of their patients had only partial remission and $4 \%$ failed to respond altogether. An alternative to radiophosphorus is treatment with chemotherapeutic substances. J. F. Wilkinson and his colleagues in Manchester introduced the use of nitrogen mustard for the treatment of proliferative conditions, including polycythaemia vera, over 20 years ago. Since then many drugs of the same type have been tested and some have proved useful in the control of polycythaemia. Lately two oiher drugs have been more widely used. The first is busulphan (Myleran), originally introduced for the treatment of chronic myeloid leukaemia. N. Wald, T. Hoshino, and M. E. Sears ${ }^{3}$ reported remissions of from 5 to 20 months after a course of treatment had brought the blood levels back to normal. The second is pyrimethamine (Daraprim), an antimalarial drug which is also a folic-acid antagonist. D. E. Pegg and H. T. Ford ${ }^{4}$ have recorded remissions of up to a year with it.

In 1964 J. Perkins, M. C. G. Israëls, and J. F. Wilkinson: gave a full account of the effect of chemotherapy in polycythaemia. Their series of 127 patients had been observed over a period of 25 years and included most of the drugs introduced during this time. They found that the average survival of their patients was the same as that found with phosphorus-32, about 13 years. Nevertheless, they pointed out that chemotherapy was more troublesome for both patient and doctor; much closer control was needed than with phosphorus-32, regular attendance for blood counts was necessary for adjustment of the dose, and all the drugs had more troublesome side-effects than radio-phosphorus. But a notable finding was that no case of acute leukaemia had occurred in their series. This had usually been regarded as one of the natural haematological complications of polycythaemia, together with myelosclerosis and marrow depression. Since leukaemia is now known to be ore of the possible results of therapeutic exposure to radiation, it became important to consider how far leukaemia as a terminal phase of

\footnotetext{
Masouredis, S. P., and Lawrence, J. H., Amer. F. med. Sci., 1957, 233, 268.$$
\text { 28, } 397 \text {. }
$$$$
\text { Wald. N., Hoshino, T., and Sears, M. E., Blood, 1958, 13, } 757 .
$$$$
\text { Pegg, D. E., and Ford, H. T., Brit. med.' F., 1961, 2, } 617 .
$$

Perkins, J., Israëls, M. C. G., and Wilkinson, J. F., Quart. F. Med., 1964, 33, 499.

Modan, B., and Lilienfeld, A. M.. Medicine (Baltimore), 1965, 44, 305. Halnan, K. E., and Russell, M. H., Lancet, 1965, 2, 760.

- Szur, L., and Lewis, S. M., Brit. F. Radiol., 1966, 39, 122.
} 